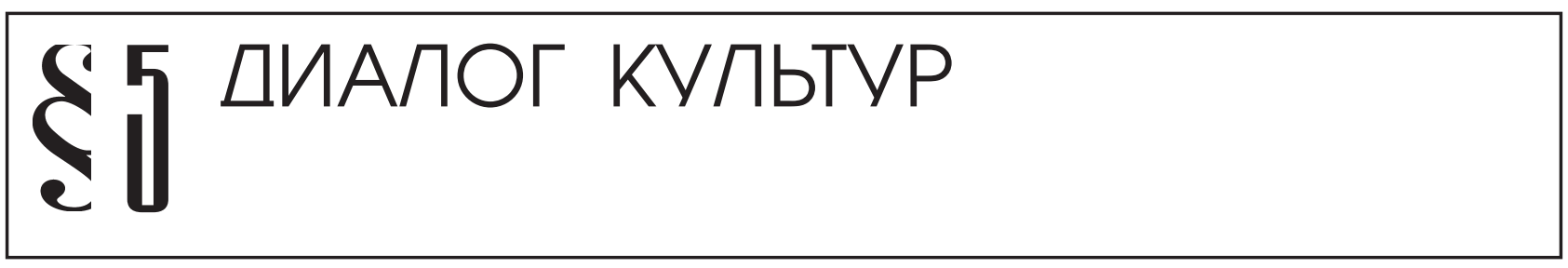

Пархоменко P.H.

\title{
РОССИЯ И ЗАПАД: ПРАВО ПРОТИВ МОРАЛИ?
}

Аннотация: B статье рассматриваются сходства и различия в духовной и правовой сферах в России и Западных странах, прежде всего, в Германии. Так, культурное своеобразие Европы можно усмотреть в том, что исторически после краха Западной Римской империи она формируется как иелостный католический мир: иерковь формирует в западно-европейских странах общую нормативную систему и единое иенностное пространство. Этот порядок был автономным и независимым от неиерковных общественных институтов и, прежде всего, от государства. Отсюда и плюрализм в Европе, и опосредованность отношений между различными институтами и общественными организациями нормативным порядком. В России отсутствие широкого класса буржуазии, недостаточное развитие правовой сферы, политическая незрелость населения предопределили «особый» путь нашей страны, равно как и ее особое положение между западным гражданским обществом и восточной деспотией. Автор подробно рассматривает различные точки зрения на проблему культурно-исторического своеобразия России и Запада в сравнении и приходит к выводу, что в России в ходе ее исторического развития возникает «своя» специфическая версия либерализма, когда место правовых гарантий свободы личности занимают гуманистические идеалы и т.н. идеал «правдыр». Таким образом, специфической чертой российского менталитета является высокая степень нагруженности либеральной идеологии и правовых норм моральными оценками.

Review: The author of the article analyzes similarities and differences in spiritual and legal spheres of life of Russia and Western countries, first of all, Germany. For example, the cultural singularity of Europe is well proved by the fact that it developed as an integral Catholic world after the failure of the Western Roman Empire. In Western European countries Church established the unified system of regulations and the common space of values. That process was autonomous and did not depend on nonreligious social institutions or government. This is what created pluralism in Europe and dependence of relations between different institutions and social organizations on legal regulations. In Russia the absence of the bourgeois class, insufficient development of the legal sphere and political immaturity of the population resulted in the 'special' path of our country and created a special position of Russia between the Western civil society and Oriental despotism. The author of the present research article in detail views different points of view on the problems of cultural and historical features of Russia compared to the West and concludes that in the course of the historical development Russia created its own specific version of liberalism when legal guarantees of personal freedom were replaced with humanist ideals including the ideal of 'truth'. Therefore, a specific feature of the Russian mentality is that Russian liberal ideology and legal regulations are in many ways based on morals and moral appraisal. Ключевые слова: Россия, Запад, Германия, право, свобода, мораль, плюрализм, государство, церковь, либерализм. Keywords: Russia, West, Germany, right, freedom, morals, pluralism, state institution, church, liberalism.

$\mathrm{P}$ азмышляя о сходствах и различиях между Россией и Западными странами, культурное своеобразие Европы можно усмотреть в том, что исторически после краха Западной Римской империи она формируется как целостный католический мир: «Церковь формировала общую нормативную систему, единое ценностное пространство, и в этом смысле ранний римский католицизм оказался «единой и единственной матрицей европейской цивилизации». Этот порядок был, во-первых, универсален для того ареала, который становился Европой; во-вторых, в сущности автономен от нецерковных общественных институтов и прежде всего - государства». ${ }^{1}$ Отсюда и плюрализм

\footnotetext{
${ }^{1}$ Капустин Б.Г. Мораль и политика в западноевропейской политической философии // Федорова М.М./Хевеши М.А. (под ред.) От абсолюта свободы к романтике равенства (Из истории политической философии). М., 1994. С. 6.
} 
в Европе, поначалу выражающийся как дуализм и противоборство Папы и Императора, церковной и секулярных традиций в общественной жизни европейских стран. Однако, как подчеркивает Капустин, здесь был важен не столько дуализм и конфликт, сколько опосредованность этих отношений в государстве нормативным порядком.

Европейские правовые нормы легитимируют и вводят в цивилизованное русло сам этот конфликт церкви и государства. Соответственно, история Европы демонстрирует нам различные этапы становления гражданского общества в европейских странах. Так, Вестфальский мир 1648 г. показал как политика может быть не только стремлением к реализации некоей идеальной модели «добра» или «хорошей» жизни, но и непосредственно технологией улаживания конфликтов в обществе, абстрагирующейся от ценностей и отказывающейся от поиска идеальной истины.

Политика становится практической прикладной дисциплиной. Таким образом, можно сказать, что модель вестфальского компромисса не как конкретный пример нахождения баланса между интересами католиков и протестантов, а как определенная формальная структура, которая может быть применена в иных подобных ситуациях, «воплотила в себе противоречие между техническими и этическими аспектами, удерживая их в некотором единстве и порождая новую динамику западной цивилизации». ${ }^{2} \mathrm{O}$ проблеме политической толерантности много писал Джон Локк.

Характеризуя политическую историю Европы из сегодняшней перспективы, Капустин полагает, что все дальнейшее развитие теории и практики Запада пошло по пути преуменьшения роли моральной компоненты в политике в сторону растущей роли «технологичности» политического процесса. Особенно наглядно это появилось в работах Ж.-Ж. Руссо и Д. Юма. По мнению Руссо моральная общность возникает вместе с общественным договором и не ранее! Юм же полагал, что моральность присуща человеческой личности - его модель «сбалансированных аффектов» личности позволяла рассматривать наличие в государстве различных партий и классов как некое естественное состояние, а не губительное (как у Руссо), для общества. Постепенно сословность английского общества XVIII в. сменяется «смешением классов» в XIX в., что ведет к возникновению феномена массового общества, когда происходит «культурная

${ }^{2}$ Там же. С. 8. нивелировка» во взглядах и мировоззрениях различных классов и групп западных обществ.

По мнению Токвилля, подлинная свобода возникает лишь в публичной сфере как явление политическое. Политика как бы разрывает сферу частного, «приватного» у конкретного индивида и, тем самым, расширяет горизонты его свободы. «В такой концепции публичности как условия и формы «расширения природы человека» происходит чрезвычайно важный переход от идеи индивидуализма (маленького, изолированного, несвободного «я» частной жизни) к идее индивидуальности (обогащенного со-бытием с другими свободными «я»)». ${ }^{3}$ Однако, по мнению Капустина, на Западе в XX в. в политике происходит практически полное устранение проблематики морали и гражданственности, а сама политика отождествляется со свободой конформистского индивидуализма в духе Хайека, т. е. мы наблюдаем абсолютное торжество «политической технологии над субстанцией морали и свободы».

А что же Россия? Отсутствие широкого класса буржуазии, недостаточное развитие правовой сферы, политическая незрелость населения - все это предопределило «особый» русский путь нашей страны, равно как и ее особое положение между западным гражданским обществом и восточной деспотией. Однако дело не только в вышеперечисленных факторах. Если мы обратимся к самым истокам становления российской государственности и нации, то мы обнаружим существенные отличия между Россией и Западом, между славянским и протестантским и католическим типами мировоззрения.

Историческая ситуация в России привела к тому, что в России справедливость всегда стояла на правом. Практика обыденной жизни была такова, что люди жили «не столько по законам, которые для всех общие, сколько по обычаям, которые были особые в разных регионах. Это было связано с историей России. Многие народы входили в состав Российской Империи добровольно, но условием такого вхождения было следующее: мы не будем жить по вашим законам, а будем жить по своим обычаям». ${ }^{4}$ По мнению Степина, имен-

\footnotetext{
${ }^{3}$ Там же. С. 27.

${ }^{4}$ Степин В.C. Ценность права и проблемы формирования правового общества в России // Баренбойм П.Д./Захаров А.В. (под ред.) Философия права в начале XXI столетия через призму конституционализма и конституционной экономики. M., 2010. C. 18.
} 


\section{Политика и общество 3 (111) • 2014}

но такое сохранение культурных и этнических особенностей новых земель, входивших в состав Российской Империи и определило своеобразие российского менталитета и российской государственной политики - в России не происходило унификации разнообразных культур, так, как это было в Западной Европе.

Сохранение в России подобных «этнических анклавов» тормозило развитие универсальных правовых законов и норм в стране, поскольку отношение и восприятие права в разных народностях было совершенно различным.

Поэтому неудивительно, что столь важный для любого западного общества кодекс юридических норм, равно как и само понятие «контракта» в русской духовной и интеллектуальной традиции зачастую оцениваются чрезвычайно негативно. С. Аверинцев в этой связи приводит в пример Ф. Достоевского, который «ненавидел самый дух морали контракта, в котором угадывал суть западного мироощущения, считал его безнадежно несовместимым с христианской братской любовью [...]. Юридический дух [...] требует, чтобы ради ограждения одного личного бытия от другого субъекты воли [...] были, подобно физическим телам, разведены в «ньютоновском» моральном пространстве, где их отношения регулируются двуединой нормой учтивости и контракта, не допускающей ни эксцессов суровости, ни эксцессов ласковости». ${ }^{5}$ На Востоке такого «опосредования» человеческих отношений учтивостью и контрактом гораздо меньше.

Еще Киреевский развивал идеи о том, что в России отсутствует рационализм западного образца, ведущий свое начало из древнеримского рационализма. Свое наибольшее развитие древнеримский рационализм получил в Римском праве. Валицкий подчеркивает, что, по мнению Киреевского, логическое совершенство Римского права было «обратной стороной внутренней атомизации римского общества. Дух его заразил западное христианство и проложил дорогу современной «логической и технической цивилизации», основывающейся на идее правового контракта изолированных рациональных индивидуумов. В таком обществе все должно быть основано на формализованных правовых договорах, поскольку внутренние органические социальные связи более не существуют». ${ }^{6}$ А гаран-

\footnotetext{
${ }_{5}^{5}$ Аверинщев С. Византия и Русь: два типа духовности // Новый мир, 1988, № 9. С. 229-230.

${ }^{6}$ Валищкий А. Философия права русского либерализма. М., 2012. C. 56.
}

тии индивидуальной свободы человека необходимы лишь для того, чтобы противостоять принципу внешнего принуждения в обществе, осуществляемому с помощью правовых норм и законов. Таким образом, по убеждению Киреевского, в западных обществах формальная законность занимает место «неформальной внутренней общности», которая произрастает из моральных убеждений и традиций общины.

Поэтому не случайно, что именно во времена Римской Империи возникает новый тип человека «человек-атом», отделившийся от Целого общины и ведущий свою частную жизнь. Российский философ Г.Д. Гачев занимает позицию, близкую к точке зрения Киреевского. Он отмечает, что Рим выработал римское право для того, чтобы «защищать и координировать интересы и собственность отдельных атомов-индивидуумов, которые теперь, видя, что порядок, закон и справедливость установились снаружи, вне человека и независимо от него, - получили основание освобождаться от совести, сей внутренней справедливости, и могли позволить себе становиться развратными и преступными». ${ }^{7}$ По мнению Гачева, юридическое сознание выносит нравственность «вовне человека - в право, во внешние установления гражданского законодательства» и, тем самым, предает индивидуума своему «индивидуализму».

Отчего же проистекает столь большое различие между российским и западным мировоззрениями? Если мы обратимся к истории, то увидим, что «русские великие князья представляли собой единый род, а константинопольский престол был открыт любому авантюристу, пришедшему ниоткуда. Важно было, что монархия на Руси не сложилась как прагматический выход из положения, но выросла из патриархальных отношений. И, наконец, есть и такая вещь, как контраст между византийской рассудочностью и русским складом души. [...] То обстоятельство, что христианская Византия получила свой политический строй от языческого Рима [...] не дало возможности христианскому сознанию ромеев пережить самодержавие как проблему. Оно не было проблемой, оно было данностью. У нас все складывалось по-иному». ${ }^{8}$

Что касается рассмотрения проблемы отношения ко злу и к власти в России и на Западе, можно обратиться, как это делает Аверинцев, к спору старцев

\footnotetext{
${ }^{7}$ Гачев Г.Д. Ментальности народов мира. М., 2008. С. 100.

${ }^{8}$ Аверинцев C. Византия и Русь: два типа духовности // Новый мир, 1988, № 7. С. 220
} 
Кириллова монастыря, которые спорили с посланием Иосифа Волоцкого об осуждении еретиков - тем не менее, они не были либералами в современном, так сказать, «англо-американском» смысле этого слова. Это не идеологи толерантности, а пророки «непостижимой для рассудка любви Бога», они учат не «терпимости», а терпению - терпению ко злу - ведь у них нет ни малейшего сомнения в том, что ересь является действительно злом. И как раз этого не было на Западе, где систематические возражения против применения насилия вылились позднее в новоевропейскую идеологию либерализма. В конечном счете подобные размышления приводят к вопросу об обосновании власти отдельной личности над другими людьми. Как решают этот вопрос западные мыслители?

По мнению Аверинцева, Запад облегчил для себя отношение к этой сложной проблеме, сделав ее «почти» - но все же не до конца! - разрешимой. Так, католическое мировоззрение делит бытие не на две «свет» и «тьма», - а на три области: между горней областью сверхъестественного, благодатного и преисподней находится еще область естественного. Государственная власть принадлежит именно к области естественного: «Если сосуществование природного, как еще-не-благодатного, с благодатью - законно, дело теологии - урегулировать отношения между той и другой областью, выяснить их границы. Это значит, качественное различие между насилием и ненасилием оказалось сведено к количественной проблеме меры, к арифметической задаче, которую всегда можно попытаться решить». ${ }^{9}$ Интересен и тот факт, что в латыни есть слово clementia, которое очень трудно перевести на русский язык. Если clementia переводится как «милосердие» - то это неправильно. В латыни для понятия «милосердие» есть термин misericordia. Аверинцев предлагает clementia переводить как «умеренность» - когда носитель власти ограничивает насилие пределами абсолютно необходимого, т.о. в этом понятии заключено больше выдержки и чувства меры, чем доброты и сострадания. Само собой, понятие clementia находится в области естественного.

И если мы сравним в этом отношении российский и западный менталитет и мировосприятие, то мы обнаружим, что в русском языке нет прямого эквивалента понятию clementia. Более того, русская духовность делит бытие не на три, а на две части - «удел света

${ }^{9}$ Аверинцев C. Византия и Русь: два типа духовности // Новый мир, 1988, № 9. С. 234. и удел мрака»! Подобное мировосприятие особенно четко проявляется в вопросе об отношению к власти в России: «Божье и Антихристово подходят друг к другу вплотную, без всякой буферной территории между ними; все, что кажется землей и земным, - на самом деле или Рай, или Ад; и носитель власти стоит точно на границе обоих царств. [...] Власть самодержавная - это нечто, находящееся либо выше человеческого мира, либо ниже его, но во всяком случае в него как бы не входящее. Благославление здесь очень трудно отделить от проклятия». ${ }^{10}$

Не здесь ли корень всех бед России и того факта, что либеральные идеи правого гражданского общества с таким трудом приживаются на российской почве? Быть может, как раз отсутствие «серединности», чувства меры, склонность к экстремумам - как раз те особенности чисто российского менталитета, которые и тормозят ассимиляцию правовых норм среди широких слоев населения у нас в стране на, так сказать, «генетическом уровне»?

Необходимо заметить, что об отсутствии т.н. «серединной культуры» в России писал в свое время еще Н. Бердяев: «У русского народа была огромная сила стихии и сравнительная слабость формы. Русский народ не был народом культуры по преимуществу, как народы Западной Европы, он был более народом откровений и вдохновений, он не знал меры и легко впадал в крайности. У народов Западной Европы все гораздо более детерминировано и оформлено, все разделено на категории и конечно». Эта особенность и является главной характеристикой русского национального самосознания, «мало способного и мало склонного удержаться на совершенных формах серединной культуры». ${ }^{11}$

Не только Бердяев, но и Ф. Степун указывает на недостаток в России культуры как инструментальной формы знаний и правового сознания в обществе: «Как стиль русской равнины и русского отношения к земле, так и стиль русского философствования явно свидетельствует о том, что религиозная тема России со своеобразным тяготением к бесформенности - с каким-то специфически русским формоборчеством. Есть нечто в русской душе (нечто очень глубокое и очень правдивое), что затрудняет всякий переход религиозной жиз-

\footnotetext{
${ }^{10}$ Там же. С. 235.

${ }^{11}$ Цит. по: Пискунов В.М. 1994: Русская идея. В кругу писателей и мыслителей русского зарубежья. М., 1994. Т. 2. C. 205, 232.
} 


\section{Политика и общество 3 (111) • 2014}

ни в религиозную культуру и тем тесно связывает русскую религиозность с некультурностью России». ${ }^{12}$

Отсутствие четко выраженного правового сознания в России и ведет к тому, что у нас антиномии власти являются задачей не рассудка, а «мучением совести». Именно так и сложился тот культурный тип личности, которая с легкостью перекладывает «чуждое бремя власти на другого» и уходит в «ложную невинность безответственности». ${ }^{13}$

На сегодня, пожалуй, большинством исследователей признается тот факт, что в России - как и прежде одной из наиболее острых проблем является проблема выбора своего исторического пути развития. Именно поэтому и возникает интерес к национальному духовному наследию и, в частности, к концепции русской идеи, к которой обращаются сегодня самые разные политические движения, партии и общественные союзы.

И это не случайно, ведь «судьба родного отечества всегда осмысливалась в русской мысли не только на прагматическо-политическом уровне, но и с точки зрения философско-исторической, когда искался высший смысл, предназначение, миссия России в мировой истории, а сам путь страны воспринимался как служение некоей цели. Более того, историософские поиски традиционно воспринимались как нечто более важное и существенное, чем построение конкретной политической модели». ${ }^{14}$ Такое обращение к русской идее, по мнению О. Волкогоновой, связано, прежде всего, с сильной мифологической компонентой общественного сознания в России. Волкогонова полагает, что: «В массовом сознании прочно занял место миф о «русской душе», который не только не был поколеблен «диким капитализмом» последних лет, но даже укрепился, стал своеобразным психологическим «убежищем» для многих моих соотечественников». ${ }^{15} \mathrm{~A}$ это, как подчеркивает Волкогонова, в свою очередь, дает нам основания для утверждения о том, что даже на исходе XX века в России миф оказался сильнее реальности. Однако, время идет, и вместе с быстрыми и радикальными изменениями на общемировой аре-

${ }^{12}$ Степун Ф.А. Жизнь и творчество: избранные сочинения. M., 2008. C. 412.

13 Аверинцев С. Византия и Русь: два типа духовности // Новый мир, 1988, № 9. С. 235.

14 Волкогонова О. «Русская идея»: мечты и реальность // Юшенков С.Н. (под ред.) Постзападная цивилизация. Либерализм: прошлое, настоящее и будущее. М., 2002. С. 158.

15 Там же. С. 160. не, также быстро изменяется и российское общество. Наибольшие изменения, как это сегодня не трудно заметить, опять-таки нам демонстрирует молодое поколение россиян.

В. Степин совершенно справедливо отмечает в этой связи: «Двадцать лет нового российского капитализма, конечно же, внесли коррективы в систему социальных ценностей. Возникло новое поколение, для которого идеалы коллективизма уже не играют той роли, которую они играли для старшего поколения. Производственный коллектив уже не воспринимается ими как второй дом. Современные социологические исследования показывают, что многие молодые люди относятся к работе в основном как к месту, где нужно зарабатывать на жизнь и делать карьеру. Индивидуальная свобода для них более престижна, чем коллективная». ${ }^{16}$

Продолжая тему «особого пути» для сравнения можно заметить, что, к примеру, в современной Германии идея «особого пути» как некоей национальной сверхидеи считается морально устаревшей. Вместо этого современные немецкие политики и политологи начали активно развивать идеи политкорректности и т.н. «мультикультурного» общества, что не является удивительным в силу большого количества эмигрантов, заполнивших как Германию, так и всю Западную Европу. По замыслу идеологов «мультикультурной идеи» все эмигранты должны безоговорочно воспринять ценности западного общества, так сказать, полностью «раствориться» в нем, утратив при этом свои собственные культурные и национальные черты. Как продолжение мультикультурной идеи можно рассматривать стремление создать единое экономическое пространство стран-членов ЕС.

Увы, реальность сегодняшнего дня демонстрирует нам всю противоречивость подобных устремлений, ведь на данный момент политика «мультикультурализма» в Германии и других западноевропейских странах, постепенно теряет кредит доверия. Также все чаще под ставится под вопрос и стремление к постоянному расширению списка стран-участников Европейского Сообщества. По всей видимости, национальное культурное своеобразие различных стран все же очень

\footnotetext{
${ }^{16}$ Степин В.C. Ценность права и проблемы формирования правового общества в России // Баренбойм П.Д./Захаров А.В. (под ред.) Философия права в начале XXI столетия через призму конституционализма и конституционной экономики. M., 2010. C. 24-25.
} 
сложно свести к некоему единому образцу, безоговорочно приемлемому для всех участников подобных процессов. В этой связи особенно интересен тот факт, что в противоположность к Германии, в России понятие «русской идеи» по-прежнему не утратило своей привлекательности. После целого ряда резко негативных оценок понятия русской идеи, хотелось бы привести примеры иного рода.

В ноябре 2010 г. в ИНИОН РАН прошла Всероссийская научная конференция «Национальная идея России», результаты работы которой были опубликованы как в виде книги, ${ }^{17}$ так и в виде электронного peсурса. На открытии этой конференции В. Якунин подчеркнул, что на сегодняшний день существует множество вариантов прочтения термина «национальная идея» - от этнических до трансцендентных категорий. К примеру, В. Соловьев говорит о национальной идее следующим образом: «Идея нации есть не то, что она о себе думает во времени, но то, что Бог думает о ней в вечности». По мнению же самого Якунина, «диапазон толкования этого понятия чрезвычайно широк: от государственной идеологии до некоего мессианства, масштаба Рах Americana, проектов «Глобальный Китай», «Исламский мир» или, кстати, «Россия в мире»». ${ }^{18}$

В ходе конференции была предпринята попытка определить четкий контекст понятия национальной идеи. Так, Якунин полагает, что национальная идея имеет положительное значение и призвана стать максимально объединяющей, примиряющей и мобилизующей идеей. Также он отождествляет понятие национальной идеи с общегосударственной категорией, поскольку «работоспособная, эффективная национальная идея - это гарантия, это ключ и это условие успешности страны». ${ }^{19}$ А конкретно национальная идея должна быть сформулирована в самой Конституции России - в Конституции должен быть сформулирован и «общенациональный девиз как идейный символ в ряду государственной символики». Однако, подчеркивает Якунин, на сегодня в России национальная идея, равно как и государственная идеология, пока еще не выработаны, поэтому необходимо самым тесным образом заняться решением этого вопроса.

\footnotetext{
${ }^{17}$ См.: Сулакиин С.С./Багдасарян В.Э. и др. (под ред.) Национальная идея России. Материалы Всероссийской научной конференции (Москва, 12 ноября 2010 г.). М., 2011.

${ }^{18}$ Там же. С. 20.

19 Там же. С. 21.
}

В заключении своего вступительного слова на открытии конференции «Национальная идея России» Якунин подчеркивает, что именно национальная идея в состоянии объединить россиян в «широком смысле представления о Родине. [...] Поэтому в Центре проблемного анализа и государственно-управленческого проектирования мы уделяем очень серьезное внимание исследованию этой темы, имея в виду, что единая национальная идея совершенно необходима России даже с точки зрения проектирования системы госуправления как научного направления исследования». ${ }^{20}$ Такие поиски совершенно необходимы и для того, чтобы народ мог бы называться народом, а не просто «населением страны», полагает Якунин.

Известный современный российский философ В. Межуев, размышляя о понятии русской идеи в современной России, приводит два противоположных мнения по этому поводу: часть российских интеллектуалов оценивает общенациональную идею в качестве возможного пути будущего развития страны как «крайне опасную глупость» (академик Д.С. Лихачев), другое мнение было хорошо сформулировано еще Ф.М. Достоевским: «Без высшей идеи не может существовать ни человек, ни нация».

Рассматривая истоки возникновения подобных национальных «сверх-идей», Межуев отмечает, что впервые в Древнем Риме появляется понятие «римской идеи», получившее свое правовое оформление в Римской республике. Позднее римская идея нашла «свое продолжение в европейской идее, где она представлена тремя классическими идеологиями Нового времени - консерватизмом, либерализмом и социализмом». ${ }^{21}$ Также и в России шел поиск идеи своей собственной цивилизационной идентичности впервые «русская идея» как специфическая характеристика России в Европе возникает где-то после победы над Наполеоном. Межуев полагает, что спор о русской идее в России был ответом на европейскую идею. В результате этого спора и появляются т.н. славянофилы, западники, евразийцы и т.п.

«Это был спор об отношении России к Европе, за которым нетрудно увидеть мучительно решаемы русской мыслью вопрос о том, чем является сама Россия,

\footnotetext{
${ }^{20}$ Там же. С. 22-23.

${ }^{21}$ Межуев B.M. «Русская идея» и цивилизационные особенности Русского мира // Гусейнов A.A/A.A. Кара-Мурза/ A.Ф. Яковлева. Русский мир как цивилизационное пространство. М., 2011. С. 11.
} 


\section{Политика и общество 3 (111) • 2014}

какое место она занимает в ансамбле европейских народов. [...] О «русской идее» писали преимущественно философы [...] их обращение к ней было обусловлено желанием не обособить Россию от Европы, а, наоборот, найти между ними нечто общее, что само по себе свидетельствовало бы об определенной европеизации русской мысли, поскольку только европейцам свойственно выражать свою культурную идентичность не только в религиозных символах, но и в философских идеях». ${ }^{22}$

Итак, можно зафиксировать, что критическое отношение к российской действительно возникает у нас в XVIII веке, причем, по мысли Межуева, такое пробуждение национального самосознания было напрямую стимулировано западными философскими идеями. Так в чем же проявилось своеобразие русской идеи, равно как и России как страны, географически находящейся между Европой и Азией?

Одна из основополагающих особенностей России - это религия православия, что отличает ее от романогерманской духовной традиции. Именно православие придает России тот особый статус, когда Московская Русь образует собой внешне и внутренне самодостаточный духовный мир, стоящий особняком от мира римско-католической церкви. Православие, таким образом, формирует специфически русское мировоззрение, но и в тоже время, тормозит диалог с Западной Европой. Правда, в нашей истории Петр I попытался преодолеть такой изоляционизм России в Европе, что позднее продолжила Екатерина II.

Так в России и возникает течение западников, которому начинает противостоять течение славянофилов: «Просветительскому «проекту модерна», славянофилы противопоставили свой проект устроения земной жизни, который можно назвать «русским проектом модерна» или «другим модерном»: выраженный в нем общественный идеал и получил впоследствии название «русской идеи»». ${ }^{23}$ По мнению Межуева, спор между славянофилами и западниками был спором об универсальности русской идеи; при этом западники искали общее и универсальное в науке и праве, а славянофилы - в религии. Таким образом, общность с Европой у славянофилов проистекала из общих духовных корней - из христианства - и лежала в прошлом; тогда как у западников эта общность была перенесена в область будущего - речь

\footnotetext{
${ }^{22}$ Там же. С. 11-12.

${ }^{23}$ Там же. С. 16.
}

шла о необходимости создания гражданского либерального общества в России.

Противоположность между Россией и Европой славянофилы трактовали как противоречие между властью и творческой свободой, а сам спор между славянофилами и западниками был «принципиальным спором» о том, как люди, «не жертвуя своей свободой могут жить в любви и согласии друг с другом, что может стать основой для такого согласия». ${ }^{24} \mathrm{Ta-}$ кой основой могло бы стать духовное единение людей в лоне христианской церкви, а идея ответственности каждого не только за себя, но и за всех составляет основу русской идеи.

Не право, а религиозная нравственная жизнь - вот что должно составлять основу общества по мнению славянофилов. Право в состоянии оградить индивидов от власти тиранов и деспотов, но не от власти капитала - именно противоречивое отношение к набирающему обороты капитализму в Западной Европе и вызывало непрекращающиеся споры между славянофилами и западниками в России. Этот спор зашел так далеко, что даже и сами западники раскололись на два противоположных течения - либералов и революционных демократов.

Для русских националистов Европа, попавшая под влияние «либерализма [...] англосаксонского типа с его повышенным пиететом перед рыночной экономикой и деньгами [...] есть антипод всего национального и самобытного». ${ }^{25}$ Поэтому Европа постепенно деградирует, тогда как Россия может способствовать духовному возрождению человечества. Универсальный характер русской идеи, отмечает Межуев, позволяет возвыситься как над европоцентрической моделью развития России, так и над этнонациональной моделью. При этом русская идея направлена в будущее на поиск возможного пути развития, преодолевающего разрыв между цивилизацией (как «тела» культуры) и культурой (как «душой» цивилизации). Русская идея постоянно напоминает нам об опасности «механического переноса» на российскую почву западный идей по причине не только консервативности России, но и «исторической ограниченности» ${ }^{26}$ самих западных идей таких, как мультикультурализм или же спекулятивная рыночная экономика англо-американского

\footnotetext{
${ }^{24}$ Межуев В.M. «Русская идея» и цивилизационные особенности Русского мира. С. 20.

${ }^{25}$ Там же. С. 30.

26 Там же. С. 45.
} 
типа - постоянные проблемы в США и ЕС и череда экономических кризисов мирового масштаба являются прямым тому подтверждением.

Вся ценность и актуальность русской идеи сегодня, по мнению Межуева, состоит в том, что русская идея «противостоит» западному универсализму и глобализму, но не как антипод, а как «особый вид, пытающийся сочетать материальные достижения западной цивилизации с духовно-нравственными запросами человеческой жизни и культуры». 27 Здесь напрямую видны параллели между российским и германским пониманием либерализма англосаксонского образца - а именно неприятие западного отношения своего «превосходства» по отношению к иным типам ментальности, мировосприятия и государственности.

Тем не менее, другой, не менее известный российский философ и политолог А.А. Кара-Мурза высказывает прямо противоположное мнение по отношению к русской идее и, соответственно, к России как носительнице особого вида государства с высоким духовно-нравственным потенциалом. По его убеждению, Россия, безусловно, выделяется из общего ряда европейских стран, но эта «особость» оценивается КараМурзой, скорее, негативно.

Одной из главных проблем российского исторического неустройства являются «крайне болезненные отношения» между консерватизмом («традицией») и реформаторством («новациями»), их «неорганичное сочетание и взаимное отталкивание». В процессе развития отечественной истории эти два течения постепенно радикализируются, консерватизм превращается в реакцию, а реформаторство доходит до своей крайней степени - нигилизма и революции. В российской истории не было места либерализму, поскольку у нас в стране на политической арене взаимодействуют лишь два вида радикализма - «реакция и революция». ${ }^{28}$ КараМурза обращается к идеям Г.П. Федотова, который полагал, что реформы Петра I придали динамизм развитию России и способствовали появлению нового культурного феномена - «русского европеизма», сочетавшего все лучшее из русского и западноевропейского культурного наследия.

27 Там же. С. 46.

${ }^{28}$ Кара-Мурза А.А. Примирение Русского мира. Возможен ли внутрицивилизационный диалог? // Гусейнов А.А/ А.А. Кара-Мурза/А.Ф. Яковлева. Русский мир как цивилизационное пространство. М., 2011. С. 153.
Однако, к несчастью для России, «русский европеизм» не смог устоять под натиском реакционных и нигилистически-революционных течений. «Нежелание и неспособность развивать русскую европейскую традицию, подмена творчества риторической псевдоевропейской стилизацией не позволили отечественным западникам укорениться в собственной истории. «Своим» для них становился далекий и, по существу, так и не понятый Запад, в то время как собственно русская история, тоже непознанная и непонятая, отрицалась и отбрасывалась». ${ }^{29}$ Поэтому русский либерализм и выродился в то, что Федотов обозначал как «чисто русское толстовство» - дворянское неприятия государственного дела.

Федотов занимался и исследованием понятия идеи свободы в его абстрактном философском смысле. По его мнению, свобода является результатом длительного развития христианской культурной традиции на Западе. Особенностью и одновременно драмой России является тот факт, что ее развитие происходило не в рамках европейского протестантизма или католицизма, а в духе восточных деспотических традиций.

Поначалу, даже в развитых европейских странах, свобода есть привилегия немногих членов общества. В восточных же деспотиях весь народ равно беззащитен перед лицом деспота. Особенностью народонаселения деспотий является особый менталитет, когда индивиды ни за что не согласны с допущением свободы лишь для отдельных членов общества - свобода или для всех, или ни для кого! Подобная трактовка понятия свободы очень легко объясняет нам всю неразбериху и хаос, которые творятся сегодня в арабских странах - там сказывается явный недостаток рационального дискурса как в политике, так и в менталитете населения. Кара-Мурза полагает, что Федотов приходит к следующему парадоксальному выводу: «тяга к всеобщему уравнению, прикрывающаяся лозунгами предельного демократизма, губительна для либеральных свобод, и - закономерно - не только не обеспечивает демократии, но и ведет к новому, еще более тяжкому деспотизму». ${ }^{30}$

Кара-Мурза, выпустивший в 1995 г. свою нашумевшую монографию о «Новом варварстве» как проблеме российской цивилизации» ${ }^{31}$ историческое и

\footnotetext{
${ }^{29}$ Там же. С. 173-174.

${ }^{30}$ Там же. С. 176.

${ }^{31}$ Кара-Мурза А.A. «Новое варварство» как проблема российской цивилизации. М., 1995.
} 


\section{Политика и общество 3 (111) • 2014}

культурное своеобразие России трактует как «дурной синтез» всего худшего из западного и восточного миров. Отсюда, вероятно, и его негативное отношение к понятию русской идеи. Кара-Мурза, в числе прочего, ссылается и на В.В. Вейдле, который полагал, что хотя Россия и является неотъемлемой частью христианской Европы, но, поскольку, христианская Европа была в свое время разделена, то ее православная часть была отброшена к Востоку. Помимо этого, Вейдле полагал, что в России «культурный слой» очень низок. Вот как раз с этим утверждением можно было бы и поспорить - по моему мнению, здесь Вейдле следовало бы разъяснить, какую культуру он имеет в виду материальную, духовную, правовую? Что касается либерально-правовых идей гражданского общества - да, здесь, без сомнения, России нечем похвастаться перед западными странами. Однако духовный потенциал нашей страны отнюдь не стремится к нулевой величине.

Рассуждая далее о культурном своеобразии России и Запада, хотелось бы обратиться к идеям известного отечественного историка Ю. Пивоварова. Пивоваров в своих работах много пишет о судьбах либерализма в России и на Западе, и в особенности в Германии. По его мнению, несмотря на все своеобразие каждой страны, общим моментом было то, что как в России, так и в Германии либерализм долгое время был очень непопулярной и даже «нелюбимой» идеологией в политических кругах. Это, в свою очередь привело к тому результату, что в XX веке в России и Германии идеи либерализма потерпели полный крах. Такое «неприятие» либеральных идей в Германии было обусловлено особенностями психологии немецкого народа.

Пивоваров ссылается на Т. Манна, который часто говорил о «провинциализме», присущим немецкой душе, что, в свою очередь, указывает на неприятие идей политической свободы в Германии. ${ }^{32}$ В Германии понятие нации не приравнивалось к понятию свободы, поскольку понимание свободы в Германии стояло очень близко к «народно-антиевропейскому», даже варварскому восприятию идеи свободы. В Германии свобода воспринималась, прежде всего, как внутренняя свобода индивида, его моральный долг. Поэтому, хотя либерализм классического западного образца в Германии и был нелюбим, тем не менее, в

${ }^{32}$ PivovarovJ. DerungeliebteLiberalismus//Luks L./O'SullivanD. (Hgg.) Russland und Deutschland im 19. Und 20. Jahrhundert: Zwei „Sonderwege“ im Vergleich. Köln/Weimar/Wien, 2001. S. 95 . немецкой культуре понятие свободы индивида все же было представлено.

В России либерализм был, так сказать, «задавлен» с одной стороны реакционной идеологией, а с другой - революционными течениями. Пивоваров подчеркивает, что хотя в политической жизни России XX века либеральные идеи играли заметную роль лишь восемь месяцев - с февраля по ноябрь 1917 г. - в политической философии России либеральные идеи получили заметное развитие. ${ }^{33}$ В истории политической мысли в России традиционно выделяется два периода: ранний «благородный» либерализм 1840-80-х гг. и «новый» либерализм начала XX столетия. На сегодняшний день в нашей стране происходит «открытие» этого нового либерализма, когда важнейшие произведения русских либеральных мыслителей начинают переиздаваться и подробно изучаться. Также Пивоваров выделяет в российском либерализме «фазу эмиграции» когда сначала крупнейшие отечественные мыслители в 1920-40-х гг. вынуждены были эмигрировать за границу, а затем в СССР возникло движение диссидентов (1960-70-е гг.).

Для того, чтобы охарактеризовать различные этапы развития российского либерализма Пивоваров ссылается на Б. Чичерина, который различал три различных типа либерализма: «либерализм улицы», когда народ выходит на улицы и учиняет беспорядки, «либерализм оппозиции», выражающийся в негативной критике господствующей власти и «консервативный охранительный либерализм», имеющий своей целью достижение истинной свободы индивида, но при этом нередко приводящий к возникновению авторитарного государства. И хотя данная типология представляется Пивоварову несколько наивной, она хорошо отражает этапы развития либеральных учений и движений в России.

Проблема при этом в том, что и сегодня наиболее распространенным типом либерального мировоззрения у нас является «либерализм улицы» и «либерализм оппозиции». Либерализм в России всегда был своего рода «внутренней эмиграцией» интеллектуалов: они пытались скрыться от наличных политических условий в область «абстрактного гуманизма». «Сегодня ситуация изменилась. Но в известной мере российские либералы сохраняют свою роль «внутренних эмигрантов». И большинству российского населения либе-

${ }^{33}$ Ibid. S. 97. 
ральные идеи чужды». ${ }^{34}$ В Германии носителем идеологии либерализма выступил средний класс, в России - дворянство и интеллектуалы, постоянно искавшие компромисс с существующей властью. Пивоваров выделяет пять следующих особенностей российского либерального движения: 1) отсутствие поддержки либеральных идей среди широких слоев населения страны; 2) антидемократический характер российского общества; 3) монархия как способ построения государства; 4) ярко выраженная консервативная направленность общественной мысли; 5) отсутствие гражданских свобод в российском обществе. ${ }^{35}$

Все это обусловило возникновение в России своей «специфической» версии либерализма, когда место правовых гарантий свободы личности заняли гуманистические идеалы, идеал «правдыl» и высокая степень нагруженности либеральной идеологии моральными оценками. Таким образом, формальные юридические нормы, обязательные для каждого члена общества, в России очень часто отягощены эмоциональной и моральной компонентами. Это очень важный момент, на который обращает внимание большинство исследователей. Поэтому и можно говорить о специфически российском менталитете, существование которого и объясняет факт того, почему юридические правовые стандарты западного образца так трудно приживаются у нас в стране.

\section{Библиография:}

1. Аверинцев С. Византия и Русь: два типа духовности // Новый мир, 1988, № 7, 9.

2. Валицкий А. Философия права русского либерализма. М., 2012. С. 56.

3. Волкогонова О. «Русская идея»: мечты и реальность // Юшенков С.Н. (под ред.) Постзападная цивилизация. Либерализм: прошлое, настоящее и будущее. М., 2002.

4. Гачев Г.Д. Ментальности народов мира. М., 2008. C. 100 .

5. Кара-Мурза А.А. «Новое варварство» как проблема российской цивилизации. М., 1995.

6. Кара-Мурза А.А. Примирение Русского мира. Возможен ли внутрицивилизационный диалог?

${ }^{34}$ Ibid. S. 99.

${ }^{35}$ Pivovarov J. Der ungeliebte Liberalismus. S. 100.
// Гусейнов А.А/А.А. Кара-Мурза/А.Ф. Яковлева. Русский мир как цивилизационное пространство. M., 2011.

7. Капустин Б.Г. Мораль и политика в западноевропейской политической философии // Федорова M.М./Хевеши М.А. (под ред.) От абсолюта свободы к романтике равенства (Из истории политической философии). М., 1994.

8. Межуев В.М. «Русская идея» и цивилизационные особенности Русского мира // Гусейнов А.А/ А.А. Кара-Мурза/А.Ф. Яковлева. Русский мир как цивилизационное пространство. М., 2011.

9. Пискунов В.М. 1994: Русская идея. В кругу писателей и мыслителей русского зарубежья. М., 1994. Т. 2.

10. Степин В.С. Ценность права и проблемы формирования правового общества в России // Баренбойм П.Д./Захаров А.В. (под ред.) Философия права в начале XXI столетия через призму конституционализма и конституционной экономики. М., 2010.

11. Степун Ф.А. Жизнь и творчество: избранные сочинения. М., 2008.

12. Сулакшин С.С./Багдасарян В.Э. и др. (под ред.) Национальная идея России. Материалы Всероссийской научной конференции (Москва, 12 ноября 2010 г.). М., 2011.

13. Pivovarov J. Der ungeliebte Liberalismus // Luks L./O’Sullivan D. (Hgg.) Russland und Deutschland im 19. Und 20. Jahrhundert: Zwei ,Sonderwege“" im Vergleich. Köln/Weimar/Wien, 2001.

14. Гуляихин В.Н. Правовой менталитет российских граждан // NB: Вопросы права и политики. - 2012. - 4. - С. 108 - 133. DOI: 10.7256/23059699.2012.4.310. URL: http://www.e-notabene.ru/lr/ article_310.html

15. Пархоменко Р.Н. Б. Чичерин о праве и принципе разделения властей // NB: Вопросы права и политики. - 2013. - 1. - С. 251 - 284. URL: http:// www.e-notabene.ru/lr/article_395.html

\section{References (transliteration):}

1. Averintsev S. Vizantiya i Rus': dva tipa dukhovnosti // Novyi mir, 1988, № 7, 9.

2. Valitskii A. Filosofiya prava russkogo liberalizma. M., 2012. S. 56.

3. Volkogonova O. «Russkaya ideya»: mechty i real'nost' // Yushenkov S.N. (pod red.) Postzapadna- 


\section{Политика и общество 3 (111) • 2014}

ya tsivilizatsiya. Liberalizm: proshloe, nastoyashchee i budushchee. M., 2002.

4. Gachev G.D. Mental'nosti narodov mira. M., 2008. S. 100 .

5. Kara-Murza A.A. «Novoe varvarstvo» kak problema rossiiskoi tsivilizatsii. M., 1995.

6. Kara-Murza A.A. Primirenie Russkogo mira. Vozmozhen li vnutritsivilizatsionnyi dialog? // Guseinov A.A/A.A. Kara-Murza/A.F. Yakovleva. Russkii mir kak tsivilizatsionnoe prostranstvo. M., 2011.

7. Kapustin B.G. Moral' i politika v zapadnoevropeiskoi politicheskoi filosofii // Fedorova M.M./Kheveshi M.A. (pod red.) Ot absolyuta svobody k romantike ravenstva (Iz istorii politicheskoi filosofii). M., 1994.

8. Mezhuev V.M. «Russkaya ideya» i tsivilizatsionnye osobennosti Russkogo mira // Guseinov A.A/ A.A. Kara-Murza/A.F. Yakovleva. Russkii mir kak tsivilizatsionnoe prostranstvo. M., 2011.

9. Piskunov V.M. 1994: Russkaya ideya. V krugu pisatelei i myslitelei russkogo zarubezh'ya. M., 1994. T. 2.

10. Stepin V.S. Tsennost' prava i problemy formirovaniya pravovogo obshchestva v Rossii // Barenboim
P.D./Zakharov A.V. (pod red.) Filosofiya prava v nachale XXI stoletiya cherez prizmu konstitutsionalizma i konstitutsionnoi ekonomiki. M., 2010.

11. Stepun F.A. Zhizn' i tvorchestvo: izbrannye sochineniya. M., 2008.

12. Sulakshin S.S./Bagdasaryan V.E. i dr. (pod red.) Natsional'naya ideya Rossii. Materialy Vserossiiskoi nauchnoi konferentsii (Moskva, 12 noyabrya 2010 g.). M., 2011.

13. Pivovarov J. Der ungeliebte Liberalismus // Luks L./O'Sullivan D. (Hgg.) Russland und Deutschland im 19. Und 20. Jahrhundert: Zwei „Sonderwege“ im Vergleich. Köln/Weimar/Wien, 2001.

14. Gulyaikhin V.N. Pravovoi mentalitet rossiiskikh grazhdan // NB: Voprosy prava i politiki. - 2012. - 4. - C. 108 - 133. DOI: 10.7256/23059699.2012.4.310. URL: http://www.e-notabene. ru/lr/article_310.html

15. Parkhomenko R.N. B. Chicherin o prave i printsipe razdeleniya vlastei // NB: Voprosy prava i politiki. 2013. - 1. - C. 251 - 284. URL: http://www.e-notabene.ru/lr/article_395.html 